\title{
Prediksi Penyakit Systemic Lupus Erythematosus Menggunakan Algoritma Genetika
}

\author{
Ramalia Noratama Putri ${ }^{1}$, Debi Setiawan ${ }^{2}$ \\ ${ }^{1}$ Program Studi Sistem Informasi Fakultas Ilmu Komputer Institut Bisnis dan Teknologi Pelita \\ Indonesia \\ ${ }^{2}$ Program Studi Teknik Informatika Fakultas Teknik Universitas Abdurrab \\ ${ }^{1} \mathrm{Jl}$. Ahmad Yani No.78-88, Pekanbaru, Riau \\ ${ }^{2}$ Jl. Riau Ujung No 73, Pekanbaru, Riau \\ e-mail: ${ }^{1}$ ramalia.noratamaputri@lecturer.pelitaindonesia.ac.id, \\ 2debisetiawan@univrab.ac.id
}

\begin{abstract}
Abstrak
Penyakit Systemic Lupus Erythematosus atau lupus adalah penyakit yang menyerang sistem imun pada jaringan tubuh. Penyakit lupus bukanlah penyakit yang menular namun termasuk penyakit yang mematikan. Berdasarkan data dari Sistem Informasi Rumah Sakit Online pada tahun 2016 terdapat 2.116 pasien menderita penyakit lupus dan 550 pasien meninggal dunia. Penyakit lupus sulit dideteksi karena gejalanya mirip dengan penyakit lain. Tujuan dari penelitian ini adalah prediksi apakah terindikasi penyakit lupus atau tidak sehingga menekan angka kematian akibat penyakit Systemic Lupus Erythematosus. Data diambil dengan cara menyebar questioner pada pasien di Rumah Sakit Umum Daerah Arifin Achmad. Metode yang tepat untuk penelitian ini adalah algoritma genetika, karena algoritma genetika memiliki akurasi lebih besar dari $94 \%$. Hasil dari penelitian ini merupakan diagnosa penyakit lupus atau tidak.
\end{abstract}

Kata kunci: Prediksi, Systemic Lupus Erythematosus, Lupus, Genetika

\section{Abstract}

Systemic Lupus Erythematosus (SLE) or lupus is a disease that attacks the immune system in body tissues. Lupus is a contagious disease but is a deadly disease. Based on data from System Rumah Sakit Online in 2016, there were 2,116 people with lupus and 550 patients who died. Lupus disease is difficult to detect because the symptoms are similar to other diseases. The aim of this study was to predict whether or not lupus was indicated to cause death due to death from PTM from SLE. The data were collected by distributing questionnaires to patients at the Arifin Achmad Regional General Hospital. The appropriate method for this research is genetic algorithm, because the genetic algorithm has an accuracy greater than $94 \%$. The results of this study were a diagnosis of lupus or not.

Keywords: Prediction, Systemic Lupus Erythematosus, Lupus, Non-Communicable Diseases, Genetics

\section{Pendahuluan}

Gaya hidup yang semakin tinggi menyebabkan masyarakat Indonesia tidak memperhatikan kesehatan mulai dari makanan dan prilaku kehidupan sehari-hari. Sehingga angka kematian dari Penyakit Tidak Menular (PTM) menjadi tinggi, salah satunya adalah penyakit Systemic Lupus Erythematosus (SLE). Meningkatnya penderita penyakit SLE dapat di lihat dari data rumah sakit yang melapor pada tahun 2016, sebanyak 2.116 pasien rawat inap yang didiagnosa penyakit lupus, dengan 550 pasien dilaporkan meninggal dunia. Tingginya kematian akibat penyakit lupus ini perlu diperhatikan, karena pada tahun 2016 terdapat $25 \%$ pasien rawat inap di rumah sakit di Indonesia berkahir kematian[1]. 
Penyakit SLE adalah penyakit sistemik yang memiliki ciri-ciri menyerang autoantibodi terhadap antigen tubuh sendiri, serhingga menyebabkan kerusakan pada organ tubuh manusia[2]. Pada keadaan normal tubuh manusia akan memproduksi dan menggunakan antibodi untuk melindungi tubuh dari virus, kuman, bakteri, dll [3]. Namun, pada pasisen SLE antibodi menyerang kembali tubuh pasien. Dampak dari penyakit SLE adalah semua sistem tubuh pasien SLE menjadi terganggu, sehingga sering terjadinya kekambuhan dan sampai saat ini belum terdapat metode penyembuhan dari penyakit SLE yang mengakibatkan pasien mengkonsumsi obat seumur hidup[4].

Kementrian kesehatan terus berupaya menekan angka kematian akibat penyakit PTM, pada tahun 2025 terdapat 9 target dalam pengendalian PTM yang harus dicapai, salah satunya adalah penyakit SLE [5]. Salah satu program untuk menekan SLE yaitu dengan cara periksa lupus sendiri (SALURI) pada Pos Pembinaan Terpadu (Posbindu) PTM. Namun diagnosis manual saat ini gagal untuk memprediksi SLE pada tahap awal. Karena prediksi penyakit SLE sulit dideteksi dari penyakit umum lainnya seperti kanker, serangan jantung dll.,[6]. Penyakit SLE merupakan jenis lupus yang memiliki gejala mirip dengan penyakit lainnya, sehingga SLE disebut dengan penyakit seribu wajah [7]. Oleh sebab itu perlu adanya suatu aplikasi berupa sistem cerdas untuk membantu masyarakat dalam mendeteksi penyakit lupus secara dini.

Sampai saai ini banyak peneliti telah menerapkan beberapa algoritma pada sistem cerdas prediksi penyakit SLE. Beberapa diantaranya, Prediksi SLE dengan menggunakan algoritma ID3. Algoritma ID3 yaitu model prediksi digunakan untuk membangun keputusan dengan pendekatan top down. Akurasi dari hasil prediksi tersebut adalah 94\%[8]. Sistem pendukung keputusan untuk prediksi kehamilan pada pasien SLE, hasil akurasi prediksi akurasi $(90,9 \%)$, sensitivitas (80,0\%), dan spesifisitas (94,1\%)[9]. Peneliti sebelumnya menggunakan Recurrent Neural Networks (RNNs) sebagai pembelajaran mesin model untuk memprediksi resiko kerusakan kronis pada SLE, hasil prediksi tersebut akurasi $77 \%$, sensitivitas $74 \%$, dan spesifikasi $76 \%$ [10].

Pada penelitian ini penulis dalam memprediksi penyakit SLE menggunakan metode algoritma genetika. Algoritma Genetika adalah suatu algoritma pencarian yang berbasis pada mekanisme seleksi alam dan genetika. Algoritma genetika telah banyak diterapkan dalam prediksi di bidang kesehatan. Peneliti sebelumnya[11]dan [12] menggunakan algoritma genetika untuk memprediksi penyakit kanker payudara dengah hasil akurasi 96\%[13]. Pada prediksi penyakit autoimun peneliti sebelumnya juga telah menerapkan algoritma genetika dengan 24 kriteria. Hasil dari penelitian tersebut membuktikan bahwa algoritma dapat memprediksi penyakit auotoimun dengan akurasi $76 \%[14]$.

\section{Metode Penelitian}

Berikut tahapan penelitian dalam menyelesaikan permasalah dalam prediksi penyakit SLE :

\subsection{Menganalisa dan Mendefenisikan Masalah}

Masalah yang diangkat pada penelitian ini adalah prediksi penyakit SLE pada manusia, penyakit SLE bukan penyakit menular tetapi penyakit yang bisa mematikan manusia.

\subsection{Menentukan capaian penelitian}

Capaian dari penelitian ini adalah sebuah keputusan apakah manusia mengidap penyakit lupus atau tidak, untuk menentukan capaian penelitian ini diperlukan penentuan variabel input dan proses yang akan dilakukan.

\subsection{Menentukan proses study literatur}

Ada dua tahapan pada study literature :

1.State Of The Art

Pada tahapan State Of The Art peneliti melihat penelitian yang sudah dilakukan sebelumnya dengan metode yang berbeda, pada topik yang sama, dengan mencari kelemahan ataupun kelebihan dari metodologi perhitungan yang disajikan.

2.Studi pustaka

Kita gunakan sebagai dasar atau landasan teori yang mendukung tercapainya penelitian ini. 


\subsection{Mengumpulkan data penelitian Questioner Sampel}

Quesitioner berupa angket diberikan pada pasien penyakit dalam di Rumah Sakit Arifin Ahmad Pekanbaru, mengenai keluhan apa yang dialimi. Pada angket diberikan skala 1-3. Pada questioner terdapat 14 pertanyaan, penyebaran quesitioner dilakukan pada bulan April 2019.Pada tahapan wawancara dilakukan pada dokter spesialis penyakit dalam, mengenai penyakit SLE. Pertanyaan pada wawancara adalah bagaimana cara mendiagnosa penyakit SLE, keluhan apa yang selalu diutarakan oleh pasien SLE, bagaimana tingkat kesembuhan penyakit SLE, dan bagaimana cara pengelompokan jenis penyakit SLE berdasarkan keluhan.

\subsection{Melakukan Perhitungan Prediksi Menggunakan Algoritma Genetika}

Algoritma Genetika (GA) adalah algoritma pencarian yang berdasarkan pada mekanisme seleksi alamiah dan genetika alamiah. Tahapan dari metode algortima genetika sebagai berikut [15]:

1. Pendefinisian Kromosom

2. Pendefinisian fungsi fitness

3. Membangkitkan sebuah populasi awal

4. Reproduksi

5. Crossover

6. Mutasi

Rangkaian proses algoritma genetika dapat digambarkan pada alur di bawah ini [16]:

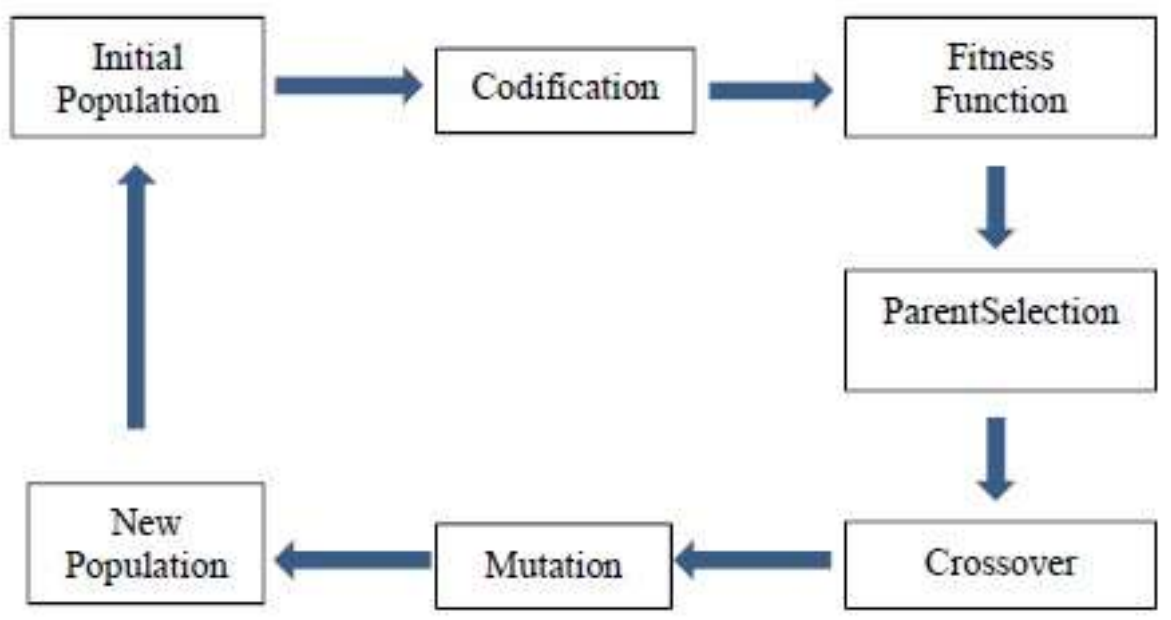

Gambar 1. Proses Algoritma Genetika

\subsection{Mengevaluasi Hasil yang didapatkan dari metode yang digunakan}

Proses Evaluasi dinilai penting, untuk menentukan kelayakan dari output yang dihasilkan, sudah sesuai dengan variabel dan proses algoritma.

\section{Hasil dan Pembahasan}

Bagian Proses pertama yang dilakukan sebelum tahap proses algoritma genetika yaitu decoding. Proses decoding adalah mengisi pembentuk individu dari kode nilai gen pada variable dari G1 sampai dengan G4. Decoding dilakukan dengan bilangan biner yang dikodekan sebagai kromosom, dimana variable input adalan 30 pasien yang dating berkunjung pada spesialis penyakit dalam. Berikut tabel 1 merupakan decoding dari variabel input algoritma genetika prediksi penyakit SLE.

Tabel 1. Decoding Kormosom Dalam Biner

\begin{tabular}{lrrrrrrrrrrrrrr}
\hline Kromosom & G1 & G2 & G3 & G4 & G5 & G6 & G7 & G8 & G9 & G10 & G11 & G12 & G13 & G14 \\
\hline Pasien 1 & 0 & 0 & 0 & 0 & 0 & 0 & 0 & 0 & 0 & 0 & 0 & 0 & 0 & 0 \\
\hline Pasien 2 & 0 & 0 & 0 & 0 & 0 & 0 & 0 & 0 & 0 & 0 & 0 & 0 & 0 & 0 \\
\hline Pasien 3 & 0 & 0 & 0 & 0 & 0 & 0 & 0 & 0 & 0 & 0 & 0 & 0 & 0 & 0 \\
\hline Pasien 4 & 0 & 1 & 0 & 0 & 1 & 1 & 0 & 0 & 1 & 0 & 0 & 0 & 0 & 0 \\
\hline Pasien 5 & 0 & 1 & 0 & 0 & 0 & 0 & 1 & 0 & 0 & 0 & 0 & 0 & 0 & 0 \\
\hline
\end{tabular}




\begin{tabular}{lrrrrrrrrrrrrrr}
\hline Kromosom & G1 & G2 & G3 & G4 & G5 & G6 & G7 & G8 & G9 & G10 & G11 & G12 & G13 & G14 \\
\hline Pasien 6 & 0 & 1 & 0 & 0 & 1 & 1 & 1 & 0 & 1 & 0 & 0 & 0 & 0 & 0 \\
\hline Pasien 7 & 0 & 0 & 0 & 0 & 0 & 0 & 1 & 0 & 0 & 0 & 0 & 0 & 0 & 0 \\
\hline Pasien 8 & 0 & 1 & 0 & 1 & 0 & 0 & 0 & 0 & 1 & 0 & 0 & 0 & 0 & 0 \\
\hline Pasien 9 & 0 & 0 & 0 & 0 & 0 & 1 & 0 & 0 & 0 & 0 & 0 & 0 & 0 & 0 \\
\hline Pasien 10 & 0 & 1 & 0 & 0 & 0 & 1 & 0 & 0 & 0 & 0 & 0 & 0 & 0 & 1 \\
\hline Pasien 11 & 1 & 1 & 0 & 1 & 0 & 0 & 1 & 0 & 0 & 0 & 0 & 0 & 0 & 0 \\
\hline Pasien 12 & 0 & 0 & 0 & 0 & 0 & 0 & 0 & 0 & 0 & 0 & 0 & 1 & 0 & 0 \\
\hline Pasien 13 & $\mathbf{0}$ & $\mathbf{0}$ & $\mathbf{0}$ & $\mathbf{0}$ & $\mathbf{0}$ & $\mathbf{0}$ & $\mathbf{0}$ & $\mathbf{0}$ & $\mathbf{0}$ & $\mathbf{0}$ & $\mathbf{0}$ & $\mathbf{0}$ & $\mathbf{0}$ & $\mathbf{0}$ \\
\hline Pasien 14 & 0 & 0 & 0 & 0 & 0 & 0 & 0 & 0 & 0 & 0 & 0 & 0 & 0 & 0 \\
\hline Pasien 15 & 0 & 1 & 0 & 0 & 0 & 0 & 0 & 0 & 1 & 0 & 0 & 0 & 0 & 0 \\
\hline Pasien 16 & 1 & 0 & 0 & 0 & 0 & 1 & 1 & 0 & 0 & 0 & 0 & 1 & 0 & 0 \\
\hline Pasien 17 & 0 & 0 & 0 & 0 & 0 & 0 & 0 & 0 & 1 & 0 & 0 & 0 & 0 & 0 \\
\hline Pasien 18 & 0 & 0 & 0 & 0 & 0 & 0 & 1 & 1 & 0 & 1 & 0 & 0 & 0 & 0 \\
\hline Pasien 19 & 0 & 0 & 0 & 0 & 0 & 0 & 1 & 0 & 1 & 0 & 0 & 0 & 0 & 0 \\
\hline Pasien 20 & 1 & 0 & 0 & 1 & 0 & 0 & 0 & 0 & 0 & 0 & 0 & 0 & 0 & 0 \\
\hline Pasien 21 & 0 & 0 & 0 & 0 & 0 & 0 & 0 & 0 & 0 & 0 & 0 & 0 & 0 & 0 \\
\hline Pasien 22 & 0 & 0 & 0 & 0 & 0 & 1 & 0 & 0 & 0 & 0 & 0 & 0 & 0 & 0 \\
\hline Pasien 23 & 0 & 0 & 1 & 0 & 0 & 0 & 0 & 0 & 0 & 0 & 0 & 0 & 0 & 0 \\
\hline Pasien 24 & 0 & 1 & 0 & 0 & 1 & 0 & 1 & 1 & 1 & 0 & 0 & 0 & 0 & 0 \\
\hline Pasien 25 & 1 & 0 & 0 & 0 & 0 & 1 & 0 & 0 & 0 & 0 & 0 & 0 & 0 & 0 \\
\hline Pasien 26 & 0 & 0 & 1 & 0 & 0 & 0 & 1 & 0 & 1 & 0 & 0 & 0 & 0 & 0 \\
\hline Pasien 27 & 0 & 0 & 0 & 0 & 0 & 0 & 0 & 0 & 0 & 0 & 0 & 0 & 0 & 0 \\
\hline Pasien 28 & 0 & 0 & 0 & 0 & 0 & 1 & 0 & 0 & 0 & 1 & 0 & 0 & 0 & 0 \\
\hline Pasien 29 & 1 & 1 & 1 & 1 & 1 & 1 & 1 & 1 & 0 & 0 & 1 & 0 & 0 & 0 \\
\hline Pasien 30 & 1 & 1 & 0 & 1 & 1 & 1 & 0 & 0 & 0 & 0 & 0 & 0 & 0 & 0 \\
\hline
\end{tabular}

\subsection{Pembentukan Cromosome}

Untuk memudahkan pembentukan cromosome maka penyakit SLE dibagi dalam 7 kelompok berdasarkan gejala penyakit. Pengelompokan penyakit terdapat 7 kelompok, yaitu Cerebral, dermatological, renal, musculoskaletal, cardiopulmonary, gastrointestinal, dan haematological. Pengelompokan kromosom dapat dilihat pada tabel 2.

Tabel 2. Pengelompokan Penyakit SLE

\begin{tabular}{lccccccccc}
\hline VARIABEL & $\begin{array}{l}\text { Cerebral } \\
\text { (OTAK) }\end{array}$ & $\begin{array}{l}\text { Dermat } \\
\text { ological } \\
\text { (KULIT } \\
\text { ) }\end{array}$ & $\begin{array}{c}\text { Renal } \\
\text { (Ginjal) }\end{array}$ & $\begin{array}{l}\text { Musculos } \\
\text { kaletal } \\
\text { (Sendi) }\end{array}$ & $\begin{array}{l}\text { Cardiopu } \\
\text { Imonary } \\
\text { (Jantung } \\
\text { dan } \\
\text { Paru- } \\
\text { Paru) }\end{array}$ & $\begin{array}{l}\text { Gastroin } \\
\text { testinal } \\
\text { (Pendara } \\
\text { San } \\
\text { Saluran } \\
\text { Cerna) }\end{array}$ & $\begin{array}{l}\text { Haema } \\
\text { tologic } \\
\text { al } \\
\text { (Penya } \\
\text { kit } \\
\text { darah) }\end{array}$ & $\begin{array}{l}\text { EVALUASI } \\
\text { CROMOS } \\
\text { OME 1- 30 }\end{array}$ & $\begin{array}{l}\text { RATA- } \\
\text { RATA } \\
\text { DANGSI } \\
\text { OBJEK } \\
\text { TIF }\end{array}$ \\
\hline $\begin{array}{l}\text { CROMOS } \\
\text { OME 1 }\end{array}$ & 0 & 0 & 0 & $\mathbf{0}$ & $\mathbf{0}$ & $\mathbf{0}$ & $\mathbf{0}$ & $\mathbf{0}$ & $\mathbf{1 6 . 4 2 2}$ \\
\hline $\begin{array}{l}\text { CROMOS } \\
\text { OME 2 }\end{array}$ & $\mathbf{0}$ & 0 & 0 & $\mathbf{0}$ & $\mathbf{0}$ & $\mathbf{0}$ & $\mathbf{0}$ & $\mathbf{0}$ & \\
\hline $\begin{array}{l}\text { CROMOS } \\
\text { OME 3 }\end{array}$ & $\mathbf{0}$ & 0 & 0 & $\mathbf{0}$ & $\mathbf{0}$ & $\mathbf{0}$ & $\mathbf{0}$ & $\mathbf{0}$ & \\
\hline $\begin{array}{l}\text { CROMOS } \\
\text { OME 4 }\end{array}$ & $\mathbf{2 1 . 4 2}$ & 0 & 7.14 & $\mathbf{0}$ & $\mathbf{0}$ & $\mathbf{0}$ & $\mathbf{0}$ & $\mathbf{2 8 . 5 6}$ & \\
\hline $\begin{array}{l}\text { CROMOS } \\
\text { OME 5 }\end{array}$ & $\mathbf{7 . 1 4}$ & & & $\mathbf{0}$ & $\mathbf{0}$ & & & \\
\hline
\end{tabular}




\begin{tabular}{|c|c|c|c|c|c|c|c|c|c|}
\hline VARIABEL & $\begin{array}{c}\text { Cerebral } \\
\text { (OTAK) }\end{array}$ & $\begin{array}{c}\text { Dermat } \\
\text { ological } \\
\text { (KULIT } \\
\text { ) }\end{array}$ & $\begin{array}{c}\text { Renal } \\
\text { (Ginjal) }\end{array}$ & $\begin{array}{c}\text { Musculos } \\
\text { kaletal } \\
\text { (Sendi) }\end{array}$ & $\begin{array}{l}\text { Cardiopu } \\
\text { lmonary } \\
\text { (Jantung } \\
\text { dan } \\
\text { Paru- } \\
\text { Paru) } \\
\end{array}$ & $\begin{array}{l}\text { Gastroin } \\
\text { testinal } \\
\text { (Pendara } \\
\text { han } \\
\text { Saluran } \\
\text { Cerna) } \\
\end{array}$ & $\begin{array}{l}\text { Haema } \\
\text { tologic } \\
\text { al } \\
\text { (Penya } \\
\text { kit } \\
\text { darah) }\end{array}$ & $\begin{array}{l}\text { EVALUASI } \\
\text { CROMOS } \\
\text { OME 1- } 30\end{array}$ & $\begin{array}{l}\text { RATA- } \\
\text { RATA } \\
\text { DARI } \\
\text { FUNGSI } \\
\text { OBJEK } \\
\text { TIF } \\
\end{array}$ \\
\hline $\begin{array}{l}\text { CROMOS } \\
\text { OME } 6\end{array}$ & 28.56 & 0 & 7.14 & 0 & 0 & o & 0 & 35.7 & \\
\hline $\begin{array}{l}\text { CROMOS } \\
\text { OME } 7\end{array}$ & 7.14 & 0 & 0 & 0 & 0.00 & 0.00 & 0.00 & 7.14 & \\
\hline $\begin{array}{l}\text { CROMOS } \\
\text { OME } 8\end{array}$ & 7.14 & 7.14 & 7.14 & 0 & 0 & 0 & 0 & 21.42 & \\
\hline $\begin{array}{l}\text { CROMOS } \\
\text { OME } 9\end{array}$ & 7.14 & 0 & 0 & 0 & 0 & 0 & 0 & 7.14 & \\
\hline $\begin{array}{l}\text { CROMOS } \\
\text { OME } 10\end{array}$ & 7.14 & 7.14 & 7.14 & 0 & 0 & 0 & 0 & 21.42 & \\
\hline $\begin{array}{l}\text { CROMOS } \\
\text { OME } 11\end{array}$ & 7.14 & 14.28 & 7.14 & 0 & 0 & 0 & 0 & 28.56 & \\
\hline $\begin{array}{l}\text { CROMOS } \\
\text { OME } 12 \\
\end{array}$ & 0 & 0 & 0 & 0 & 7.14 & 0 & 0 & 7.14 & \\
\hline $\begin{array}{l}\text { CROMOS } \\
\text { OME } 13\end{array}$ & 0 & 0 & 0 & 0 & 0 & 0 & 0 & 0 & \\
\hline $\begin{array}{l}\text { CROMOS } \\
\text { OME } 14\end{array}$ & 0 & 0 & 0 & 0 & 0 & 0 & 0 & 0 & \\
\hline $\begin{array}{l}\text { CROMOS } \\
\text { OME } 15\end{array}$ & 7.14 & 0 & 7.14 & 0 & 0 & 0 & 0 & 14.28 & \\
\hline $\begin{array}{l}\text { CROMOS } \\
\text { OME } 16\end{array}$ & 14.28 & 7.14 & 0 & 0 & 7.14 & 0 & 0 & 28.56 & \\
\hline $\begin{array}{l}\text { CROMOS } \\
\text { OME } 17\end{array}$ & 7.14 & 0 & 0 & 0 & 0 & 0 & 0 & 7.14 & \\
\hline $\begin{array}{l}\text { CROMOS } \\
\text { OME } 18\end{array}$ & 7.14 & 7.14 & 0 & 0 & 7.14 & 0 & 0 & 21.42 & \\
\hline $\begin{array}{l}\text { CROMOS } \\
\text { OME } 19\end{array}$ & 14.28 & 0 & 0 & 0 & 0 & 0 & 0 & 14.28 & \\
\hline $\begin{array}{l}\text { CROMOS } \\
\text { OME } 20 \\
\end{array}$ & 0 & 14.28 & 0 & 0 & 0 & 0 & 0 & 14.28 & \\
\hline $\begin{array}{l}\text { CROMOS } \\
\text { OME } 21\end{array}$ & 0 & 0 & 0 & 0 & 0 & 0 & 0 & 0 & \\
\hline $\begin{array}{l}\text { CROMOS } \\
\text { OME } 22\end{array}$ & 7.14 & 0 & 0 & 0 & 0 & 0 & 0 & 7.14 & \\
\hline $\begin{array}{l}\text { CROMOS } \\
\text { OME } 23\end{array}$ & 7.14 & 0 & 0 & 0 & 7.14 & 0 & 0 & 14.28 & \\
\hline $\begin{array}{l}\text { CROMOS } \\
\text { OME } 24\end{array}$ & 21.42 & 7.14 & 7.14 & 0 & 0 & 0 & 0 & 35.7 & \\
\hline $\begin{array}{l}\text { CROMOS } \\
\text { OME } 25\end{array}$ & 7.14 & 7.14 & 0 & 0 & 0 & 0 & 0 & 14.28 & \\
\hline $\begin{array}{l}\text { CROMOS } \\
\text { OME } 26\end{array}$ & 21.42 & 0 & 0 & 0 & 7.14 & 0 & 0 & 28.56 & \\
\hline $\begin{array}{l}\text { CROMOS } \\
\text { OME } 27\end{array}$ & 0 & 0 & 0 & 0 & 0 & 0 & 0 & 0 & \\
\hline
\end{tabular}




\begin{tabular}{|c|c|c|c|c|c|c|c|c|c|}
\hline VARIABEL & $\begin{array}{l}\text { Cerebral } \\
\text { (OTAK) }\end{array}$ & $\begin{array}{c}\text { Dermat } \\
\text { ological } \\
\text { (KULIT } \\
\text { ) }\end{array}$ & $\begin{array}{c}\text { Renal } \\
\text { (Ginjal) }\end{array}$ & $\begin{array}{c}\text { Musculos } \\
\text { kaletal } \\
\text { (Sendi) }\end{array}$ & $\begin{array}{l}\text { Cardiopu } \\
\text { lmonary } \\
\text { (Jantung } \\
\text { dan } \\
\text { Paru- } \\
\text { Paru) } \\
\end{array}$ & $\begin{array}{l}\text { Gastroin } \\
\text { testinal } \\
\text { (Pendara } \\
\text { han } \\
\text { Saluran } \\
\text { Cerna) }\end{array}$ & $\begin{array}{l}\text { Haema } \\
\text { tologic } \\
\text { al } \\
\text { (Penya } \\
\text { kit } \\
\text { darah) } \\
\end{array}$ & $\begin{array}{l}\text { EVALUASI } \\
\text { CROMOS } \\
\text { OME 1- } 30\end{array}$ & $\begin{array}{l}\text { RATA- } \\
\text { RATA } \\
\text { DARI } \\
\text { FUNGSI } \\
\text { OBJEK } \\
\text { TIF } \\
\end{array}$ \\
\hline $\begin{array}{l}\text { CROMOS } \\
\text { OME } 28\end{array}$ & 7.14 & 0 & 0 & 0 & 7.14 & 0 & 0 & 14.28 & \\
\hline $\begin{array}{l}\text { CROMOS } \\
\text { OME } 29 \\
\end{array}$ & 35.7 & 21.42 & 7.14 & 0 & 7.14 & 0 & 0 & 71.4 & \\
\hline $\begin{array}{l}\text { CROMOS } \\
\text { OME } 30\end{array}$ & 14.28 & 14.28 & 7.14 & 0 & 0 & 0 & 0 & 35.7 & \\
\hline
\end{tabular}

\subsection{Seleksi Cromosome}

Setelah proses decoding dan pengelompokan chromosome berdasarkan kelompok penyakit SLE, maka tahap selanjutnya adalah proses Seleksi Cromosome. Seleksi chromosome adalah membuat chromosome dengan fungsi objektif kecil memiliki peluang lebih besar, dengan menggunakan fungsi fitness $=(1 /(1+$ fungsi_objektif $))$. Untuk menghindari kesalahan pembagian 0 maka fungsi objektif perlu ditambah 1 .hasil seleksi chromosome dapat dilihat pada tabel 3.

Tabel 3. Seleksi Cromosome

\begin{tabular}{|c|c|c|c|c|c|c|}
\hline FITNES 1 & 1 & $\begin{array}{l}\text { TOTAL } \\
\text { FITNES }\end{array}$ & $\begin{array}{l}\text { PROBABILITAS } \\
\text { FITNESS }\end{array}$ & $\begin{array}{l}\text { RUMUS : } \\
\text { P[i] = } \\
\text { fitness[i] / } \\
\text { total_fitness }\end{array}$ & $\begin{array}{l}\text { KON } \\
\text { PRO }\end{array}$ & $\begin{array}{l}\text { LATIF } \\
\text { BILITAS }\end{array}$ \\
\hline FITNES 2 & 1 & 9.437048918 & P1 & 0.105965 & $\mathrm{C} 1$ & 0.105965 \\
\hline FITNES 3 & 1 & & $\mathrm{P} 2$ & 0.105965 & $\mathrm{C} 2$ & 0.218866 \\
\hline FITNES 4 & 0.033829499 & & P3 & 0.105965 & $\mathrm{C} 3$ & 0.324831 \\
\hline FITNES 5 & 0.065445026 & & P4 & 0.003585 & $\mathrm{C} 4$ & 0.328416 \\
\hline FITNES 6 & 0.027247956 & & P5 & 0.006935 & $\mathrm{C} 5$ & 0.335351 \\
\hline FITNES 7 & 0.122850123 & & P6 & 0.002887 & C6 & 0.338238 \\
\hline FITNES 8 & 0.044603033 & & P7 & 0.013018 & $\mathrm{C} 7$ & 0.351256 \\
\hline FITNES 9 & 0.122850123 & & $\mathrm{P} 8$ & 0.004726 & $\mathrm{C} 8$ & 0.355982 \\
\hline FITNES 10 & 0.044603033 & & $\mathrm{P9}$ & 0.013018 & $\mathrm{C} 9$ & 0.369 \\
\hline FITNES 11 & 0.033829499 & & P10 & 0.004726 & $\mathrm{C} 10$ & 0.373726 \\
\hline FITNES 12 & 0.122850123 & & P11 & 0.003585 & $\mathrm{C} 11$ & 0.377311 \\
\hline FITNES 13 & 1 & & P12 & 0.013018 & $\mathrm{C} 12$ & 0.390329 \\
\hline FITNES 14 & 1 & & P13 & 0.105965 & $\mathrm{C} 13$ & 0.496294 \\
\hline FITNES 15 & 0.065445026 & & P14 & 0.105965 & C14 & 0.60226 \\
\hline FITNES 16 & 0.033829499 & & P15 & 0.006935 & $\mathrm{C} 15$ & 0.60226 \\
\hline FITNES 17 & 0.122850123 & & P16 & 0.003585 & $\mathrm{C} 16$ & 0.605844 \\
\hline FITNES 18 & 0.044603033 & & P17 & 0.013018 & $\mathrm{C} 17$ & 0.618862 \\
\hline FITNES 19 & 0.065445026 & & P18 & 0.004726 & $\mathrm{C} 18$ & 0.623589 \\
\hline
\end{tabular}




\begin{tabular}{|c|c|c|c|c|c|c|}
\hline \multirow{2}{*}{$\begin{array}{l}\text { FITNES } 1 \\
\text { FITNES } 20\end{array}$} & \multirow{2}{*}{$\begin{array}{c}1 \\
0.065445026\end{array}$} & \multirow{2}{*}{$\begin{array}{l}\text { TOTAL } \\
\text { FITNES } \\
\end{array}$} & \multirow{2}{*}{$\begin{array}{l}\text { PROBABILITAS } \\
\text { FITNESS } \\
\text { P19 }\end{array}$} & \multirow{2}{*}{$\begin{array}{l}\begin{array}{l}\text { RUMUS : } \\
\text { P[i] = } \\
\text { fitness[i] / } \\
\text { total_fitness }\end{array} \\
0.006935\end{array}$} & \multicolumn{2}{|c|}{$\begin{array}{l}\text { KOMULATIF } \\
\text { PROBABILITAS }\end{array}$} \\
\hline & & & & & C19 & 0.630524 \\
\hline FITNES 21 & 1 & & $\mathrm{P} 20$ & 0.006935 & $\mathrm{C} 20$ & 0.637458 \\
\hline FITNES 22 & 0.122850123 & & $\mathrm{P} 21$ & 0.105965 & $\mathrm{C} 21$ & 0.743424 \\
\hline FITNES 23 & 0.065445026 & & P22 & 0.013018 & $\mathrm{C} 22$ & 0.756442 \\
\hline FITNES 24 & 0.027247956 & & $\mathrm{P} 23$ & 0.006935 & $\mathrm{C} 23$ & 0.763376 \\
\hline FITNES 25 & 0.065445026 & & P24 & 0.002887 & $\mathrm{C} 24$ & 0.766264 \\
\hline FITNES 26 & 0.033829499 & & P25 & 0.006935 & $\mathrm{C} 25$ & 0.773199 \\
\hline FITNES 27 & 1 & & P26 & 0.003585 & $\mathrm{C} 26$ & 0.776783 \\
\hline FITNES 28 & 0.065445026 & & P27 & 0.105965 & $\mathrm{C} 27$ & 0.882749 \\
\hline FITNES 29 & 0.013812155 & & $\mathrm{P} 28$ & 0.006935 & $\mathrm{C} 28$ & 0.889684 \\
\hline FITNES 30 & 0.027247956 & & P29 & 0.001464 & C29 & 0.891147 \\
\hline FITNES 31 & 1 & & P30 & 0.002887 & C30 & 0.894035 \\
\hline
\end{tabular}

\subsection{Roulete Whele Selection}

Roulete Whele selection adalah proses pensortiran parents "orang tua" berdasarkan nilai yang cocok (Fitness). Hal ini juga disebut sebagai proses pembangkitan bilangan acak R atau roulete whele dengan NILAI R[K] RANGE 0-1 ATAU Angka acak lebih besar dari atau sama dengan 0 dan kurang dari 1 Contoh : nilai median dari C1,C2 sampai ke cn. Keterangan Nilai Pertama : Bernilai True apabila Nilai $\mathrm{R} 1>\mathrm{C} 1$ dan $\mathrm{R} 1<\mathrm{C} 2$ Contoh :

$\mathrm{R} 1=0.1624$

$\mathrm{C} 1=0.1060$

$\mathrm{C} 2=0.2189$

$0.1624>0.1060$ dan $0.1624<0.2189=$ True/ Kondisi Terpenuhi.

Nilai Ke Empat :

Bernilai False atau disebut juga dengan posisi Cut Point, apabila semua nilai, bernilai sama atau salah satu nilai bernilai kecil atau salah satu nilai bernilai besar. Contoh : R14>C14 dan R14<C15 Maka : jawabannya adalah salah atau false karena R4,C4,C5 Nilainya adalah sama.

$\mathrm{R} 14=0.6023$

$\mathrm{C} 14=0.6023$

$\mathrm{C} 15=0.6023$

$0.6023>0.6023$ dan $0.6023<0.6023=$ False $/$ Kondisi tidak terpenuhi.

Tabel 4. Hasil Roulete Whele Selection

\begin{tabular}{lll}
\hline \multicolumn{1}{c}{ Roulete Whele } & RK & Pengujian RK \\
\hline R1 & 0.1624 & TRUE \\
\hline R2 & 0.2718 & TRUE \\
\hline R3 & 0.3266 & TRUE \\
\hline R4 & 0.3319 & TRUE \\
\hline R5 & 0.3368 & TRUE \\
\hline R6 & 0.3447 & TRUE \\
\hline
\end{tabular}




\begin{tabular}{|c|c|c|}
\hline Roulete Whele & RK & Pengujian RK \\
\hline R7 & 0.3536 & TRUE \\
\hline $\mathrm{R} 8$ & 0.3625 & TRUE \\
\hline R9 & 0.3714 & TRUE \\
\hline $\mathrm{R} 10$ & 0.3755 & TRUE \\
\hline $\mathrm{R} 11$ & 0.3838 & TRUE \\
\hline R12 & 0.4433 & TRUE \\
\hline $\mathrm{R} 13$ & 0.5493 & TRUE \\
\hline $\mathrm{R} 14$ & 0.6023 & FALSE \\
\hline $\mathrm{R} 15$ & 0.6041 & TRUE \\
\hline $\mathrm{R} 16$ & 0.6124 & TRUE \\
\hline $\mathrm{R} 17$ & 0.6212 & TRUE \\
\hline $\mathrm{R} 18$ & 0.6271 & TRUE \\
\hline R19 & 0.6340 & TRUE \\
\hline R20 & 0.6904 & TRUE \\
\hline R21 & 0.7499 & TRUE \\
\hline R22 & 0.7599 & TRUE \\
\hline $\mathrm{R} 23$ & 0.7648 & TRUE \\
\hline R24 & 0.7697 & TRUE \\
\hline $\mathrm{R} 25$ & 0.7750 & TRUE \\
\hline R26 & 0.8298 & TRUE \\
\hline $\mathrm{R} 27$ & 0.8862 & TRUE \\
\hline R28 & 0.8904 & TRUE \\
\hline R29 & 0.8926 & TRUE \\
\hline R30 & 0.8940 & FALSE \\
\hline
\end{tabular}

\subsection{Proses Seleksi}

Pada proses seleksi yaitu memilih populasi baru, dengan menentukan nilai terkecil dan terbesar. Caranya di lakukan proses sortir antara nilai terkecil atau "minimum" yaitu 7.14 dan nilai terbesar "maximum" 71.40. pada tabel 5 merupakan hasil proses seleksi.

Tabel 5. Proses Seleksi

\begin{tabular}{llcr}
\hline \multicolumn{2}{c}{ PROSES SELEKSI } & \multicolumn{2}{c}{ HASIL PROSES SELEKSI } \\
CROMOSOME & \multicolumn{1}{c}{ RK } & CROMOSOME & \multicolumn{1}{c}{ NILAI RK } \\
\hline CHROMOSOME 1 & CROMOSOME 29 & 0.00 & 71.40 \\
\hline CHROMOSOME 2 & CROMOSOME 29 & 0.00 & 71.40 \\
\hline CHROMOSOME 3 & CROMOSOME 29 & 0.00 & 71.40 \\
\hline CHROMOSOME 4 & CROMOSOME 29 & 28.56 & 7.14 \\
\hline CHROMOSOME 5 & CROMOSOME 29 & 14.28 & 7.14 \\
\hline CHROMOSOME 6 & CROMOSOME 29 & 35.70 & 7.14 \\
\hline CHROMOSOME 7 & CROMOSOME 29 & 7.14 & 71.40 \\
\hline CHROMOSOME 8 & CROMOSOME 29 & 21.42 & 7.14 \\
\hline CHROMOSOME 9 & CROMOSOME 29 & 7.14 & 71.40 \\
\hline
\end{tabular}




\begin{tabular}{llcr}
\hline \multicolumn{1}{c}{ PROSES SELEKSI } & \multicolumn{2}{c}{ HASIL PROSES SELEKSI } \\
\hline CROMOSOME & \multicolumn{1}{c}{ RK } & $\begin{array}{c}\text { NILAI } \\
\text { CROMOSOME }\end{array}$ & NILAI RK \\
\hline CHROMOSOME 10 & CROMOSOME 29 & 21.42 & 7.14 \\
\hline CHROMOSOME 11 & CROMOSOME 29 & 28.56 & 7.14 \\
\hline CHROMOSOME 12 & CROMOSOME 29 & 7.14 & 71.40 \\
\hline CHROMOSOME 13 & CROMOSOME 29 & 0.00 & 71.40 \\
\hline CHROMOSOME 14 & CROMOSOME 14 & 0.00 & 71.40 \\
\hline CHROMOSOME 15 & CROMOSOME 29 & 14.28 & 7.14 \\
\hline CHROMOSOME 16 & CROMOSOME 29 & 28.56 & 7.14 \\
\hline CHROMOSOME 17 & CROMOSOME 29 & 7.14 & 71.40 \\
\hline CHROMOSOME 18 & CROMOSOME 29 & 21.42 & 7.14 \\
\hline CHROMOSOME 19 & CROMOSOME 29 & 14.28 & 7.14 \\
\hline CHROMOSOME 20 & CROMOSOME 29 & 14.28 & 7.14 \\
\hline CHROMOSOME 21 & CROMOSOME 29 & 0.00 & 71.40 \\
\hline CHROMOSOME 22 & CROMOSOME 29 & 7.14 & 71.40 \\
\hline CHROMOSOME 23 & CROMOSOME 29 & 14.28 & 7.14 \\
\hline CHROMOSOME 24 & CROMOSOME 29 & 35.70 & 7.14 \\
\hline CHROMOSOME 25 & CROMOSOME 29 & 14.28 & 7.14 \\
\hline CHROMOSOME 26 & CROMOSOME 29 & 28.56 & 7.14 \\
\hline CHROMOSOME 27 & CROMOSOME 29 & 0.00 & 71.40 \\
\hline CHROMOSOME 28 & CROMOSOME 29 & 14.28 & 7.14 \\
\hline CHROMOSOME 29 & CROMOSOME 29 & 71.40 & 7.14 \\
\hline CHROMOSOME 30 & CROMOSOME 29 & 35.70 & 7.14 \\
\hline
\end{tabular}

\subsection{Crossover}

Proses crossover adalah saling menukar gen dengan pemilihan secara acak posisi chromosome induk, oleh parameter crossover_rate ( $\rho$ c ) atau rata-rata hasil persilangan yang mempengaruhi jumlah chromosome. Pada table 6 merupakan hasil dari proses crossover.

Tabel 6. Crossover

\begin{tabular}{lr}
\hline \multicolumn{1}{c}{ CROSSOVER } & Evaluasi \\
\hline CHROMOSOME 1 & 0.00 \\
\hline CHROMOSOME 2 & 0.00 \\
\hline CHROMOSOME 3 & 0.00 \\
\hline CHROMOSOME 4 & 1353.19 \\
\hline CHROMOSOME 5 & 1691.49 \\
\hline CHROMOSOME 6 & 85.36 \\
\hline CHROMOSOME 7 & 507.45 \\
\hline CHROMOSOME 8 & 51.22 \\
\hline CHROMOSOME 9 & 507.45 \\
\hline CHROMOSOME 10 & 2029.79 \\
\hline CHROMOSOME 11 & 68.29 \\
\hline
\end{tabular}




\begin{tabular}{ccc}
\hline CROSSOVER & Evaluasi & \\
\hline CHROMOSOME 12 & 0.00 \\
\hline CHROMOSOME 13 & 0.00 \\
\hline
\end{tabular}

\subsection{Mutasi Gen}

Mutasi gen merupakan penggantian gen yang dipilih dengan cara acak dari hasil crossover cromosome dengan nilai baru yang didapat secara acak. Pada tabel 7 adalah hasil mutasi gen.

Tabel 7.Mutasi Gen

\begin{tabular}{lrr}
\hline Gen & \multicolumn{1}{l}{ CROSSOVER } & \multicolumn{1}{c}{ TOTAL MUTASI PERCROMOSOME } \\
\hline $\mathrm{C} 1$ & 0 & 0 \\
\hline $\mathrm{C} 2$ & 0 & 0 \\
\hline $\mathrm{C} 3$ & 0 & 0 \\
\hline $\mathrm{C} 4$ & 57.12 & 399.84 \\
\hline $\mathrm{C} 5$ & 71.4 & 499.8 \\
\hline $\mathrm{C} 6$ & 3.57 & 24.99 \\
\hline $\mathrm{C} 7$ & 21.42 & 149.94 \\
\hline $\mathrm{C} 8$ & 2.142 & 14.994 \\
\hline $\mathrm{C} 9$ & 21.42 & 149.94 \\
\hline $\mathrm{C} 10$ & 85.68 & 599.76 \\
\hline $\mathrm{C} 11$ & 2.856 & 19.992 \\
\hline $\mathrm{C} 12$ & 0 & 0 \\
\hline $\mathrm{C} 13$ & 0 & 0 \\
\hline & &
\end{tabular}

\subsection{Rata-Rata Fungsi Objektif}

Untuk mencari nilai fungsi objektif setiap total cromosome di C1-C13 dikurangi 1. Untuk mencari Rata-rata Fungsi objektif rumus yang digunakan adalah nilai fungsi objektif/7.tujuh disini berarti tujuh jenis penyakit SLE, yaitu Cerebral (OTAK), Dermatological (KULIT), Renal (Ginjal), Musculoskaletal (Sendi), Cardiopulmonary (Jantung dan Paru-Paru), Gastrointestinal (Pendarahan Saluran Cerna), Haematological (Penyakit darah) Keputusan didapat dari rumus persamaan. Lakukan Hinggga Iterasi Ke-N Untuk Mencapai Crhomosome Terbaik, Pada Generasi Keberapa Dan Mencapai Nilai Optimal >=(Kriteria) Pertanyaan Terjawab Benar, Terindentifikasi Penyakit Sle Dengan Menggunakan Persamaan 5 persamaan, Sebagai berikut :

1. $\mathrm{f}=\mathrm{a}+\mathrm{b}+\mathrm{c}+\mathrm{d} \ldots \mathrm{x}>=42.86$ (Cerebral) $: 42.86$ didapat dari 6 Kondisi pertanyaan $* 7.14$ bobot point / 1 pertanyaan.

2. $\mathrm{f}=\mathrm{a}+\mathrm{b}+\mathrm{c}+\mathrm{d} \ldots \mathrm{x}>=28.57$ (Dermatological) : 28.57 didapat dari 4 kondisi pertanyaan * 7.14 bobot point / 1 pertanyaan.

3. $\mathrm{f}=\mathrm{a}+\mathrm{b}+\mathrm{c}+\mathrm{d} \ldots \mathrm{x}>=7.14$ (Renal) $: 7.14$ didapat dari 1 kondisi pertanyaan $* 7.14$ bobot point / 1 pertanyaan.

4. $\mathrm{f}=\mathrm{a}+\mathrm{b}+\mathrm{c}+\mathrm{d} \ldots \mathrm{x}>=7.14$ (Musculoskaletal) : 1 didapat dari 1 kondisi pertanyaan $* 7.14$ bobot point / 1 pertanyaan.

5. $\mathrm{f}=\mathrm{a}+\mathrm{b}+\mathrm{c}+\mathrm{d} \ldots \mathrm{x}>=14.29$ (Cardiopulonory) : 14.29 didapat dari 2 kondisi pertanyaan * 7.14 bobot point / 1 pertanyaan.

6. Jika nilainya tidak memenuhi persamaan maka FALSE atau tidak ada indikasi penyakit. 
Tabel 8.Rata-Rata Fungsi Objektif C1-C13

\begin{tabular}{|c|c|c|c|}
\hline \multirow[b]{2}{*}{ Gen } & \\
\hline & $\begin{array}{l}\text { Fungsi } \\
\text { Objektif }\end{array}$ & Rata-Rata Fungsi Objektif & Hasil \\
\hline $\mathrm{C} 1$ & $-1,00$ & $-0,14$ & FALSE \\
\hline $\mathrm{C} 2$ & $-1,00$ & $-0,14$ & FALSE \\
\hline $\mathrm{C} 3$ & $-1,00$ & $-0,14$ & FALSE \\
\hline $\mathrm{C} 4$ & 398,84 & 56,98 & CEREBRAL \\
\hline $\mathrm{C} 5$ & 498,80 & 71,26 & CEREBRAL \\
\hline C6 & 23,99 & 3,43 & FALSE \\
\hline $\mathrm{C} 7$ & 148,94 & 21,28 & RENAL \\
\hline $\mathrm{C} 8$ & 13,99 & 2,00 & FALSE \\
\hline C9 & 148,94 & 21,28 & RENAL \\
\hline $\mathrm{C} 10$ & 598,76 & 85,54 & CEREBRAL \\
\hline $\mathrm{C} 11$ & 18,99 & 2,71 & FALSE \\
\hline $\mathrm{C} 12$ & $-1,00$ & $-0,14$ & FALSE \\
\hline $\mathrm{C} 13$ & $-1,00$ & $-0,14$ & FALSE \\
\hline
\end{tabular}

Tabel 9.Rata-Rata Fungsi Objektif C14-C30

\begin{tabular}{|c|c|c|c|}
\hline Gen & $\begin{array}{l}\text { Fungsi } \\
\text { Objektif }\end{array}$ & & Hasil \\
\hline $\mathrm{C} 14$ & -1 & $-0,14$ & FALSE \\
\hline $\mathrm{C} 15$ & 399 & 56,98 & CEREBRAL \\
\hline $\mathrm{C} 16$ & 19 & 2,71 & FALSE \\
\hline $\mathrm{C} 17$ & 149 & 21,28 & RENAL \\
\hline $\mathrm{C} 18$ & 199 & 28,42 & RENAL \\
\hline $\mathrm{C} 19$ & 199 & 28,42 & RENAL \\
\hline $\mathrm{C} 20$ & -1 & $-0,14$ & FALSE \\
\hline $\mathrm{C} 21$ & -1 & $-0,14$ & FALSE \\
\hline $\mathrm{C} 22$ & 99 & 14,14 & RENAL \\
\hline $\mathrm{C} 23$ & 499 & 71,26 & CEREBRAL \\
\hline $\mathrm{C} 24$ & 499 & 71,26 & CEREBRAL \\
\hline $\mathrm{C} 25$ & 399 & 56,98 & CEREBRAL \\
\hline $\mathrm{C} 26$ & -1 & $-0,14$ & FALSE \\
\hline $\mathrm{C} 27$ & -1 & $-0,14$ & FALSE \\
\hline $\mathrm{C} 28$ & 999 & 142,66 & CEREBRAL \\
\hline $\mathrm{C} 29$ & 2498 & 356,86 & CEREBRAL \\
\hline $\mathrm{C} 30$ & 249 & 35,56 & DERMATOLOGICAL \\
\hline
\end{tabular}

Tabel 10. Hasil Prediksi SLE

\begin{tabular}{lll}
\hline \multicolumn{1}{c}{ Prediksi } \\
\hline $\mathrm{C} 1-13$ & Cerebral & 3 \\
& Renal & 2 \\
& Tidak sakit & 8 \\
$\mathrm{C} 14-30$ & Cerebral & 6 \\
& Renal & 4 \\
& Dermatological & 1 \\
& Tidak Sakit & 6 \\
\hline Total & & 30 \\
\hline
\end{tabular}

Proses iterasi terus berlanjut sampai memperoleh nilai terbaik, yaitu pada iterasi mencapai nilai optimal dari pertanyaan yang benar. Pada penelitian ini hasil pada proses genetika setelah 
dapat populasi genetika yang terbaik pada iterasi ke 2 karena dileterasi kedua sudah menunjukan jumlah penderita yang menderita sakit cerebral renal dan dermatological.

\section{Kesimpulan}

Penelitian ini membuktikan bahwa algoritma genetika dapat melakukan prediksi penyakit SLE, dari tabel 10 dapat dilihat bahwa di temui 14 pasien yang tidak terdeteksi penyakit SLE dari 30 pasien, 9 orang pasien terdeteksi penyakit SLE yang menyerang otak (Cerebral), 6 orang pasien terdeteksi penyakit SLE yang menyerang ginjal (Renal), 1 orang pasien terdeteksi penyakit SLE yang menyerang kulit (dermatological). Apabila terindikasi penyakit SLE maka pasien disarankan memeriksakan lebih lanjut pada Rumah Sakit. Dengan adanya penerapan algoritma genetika pada prediksi penyakit SLE dapat menekan angka kematian akibat PTM teruma akibat penyakit SLE. Hasil dari perhitungan algoritma genetika ini akan dikembangkan menjadi aplikasi. Diharapkan aplikasi yang dibuat dapat digunakan oleh masyarakat. Sehingga masyarakat dapat melakukan periksa Lupus sendiri menggunakan aplikasi.

\section{Ucapan Terimakasih}

Ucapan terimakasih kami sampaikan kepada Direktorat Riset dan Pengabdian Masyarakat Direktorat Jenderal Penguatan Riset dan Pengembangan Kementrian Riset, Teknologi, dan Pendidikan Tinggi atas pendanaan Penelitian Dosen Pemula (PDP) Tahun Pelaksanaan 2019

\section{Daftar Pustaka}

[1] K. K. RI, Situasi Lupus di Indonesia. Jakarta, 2017.

[2] V. I. Poespitasari, A. A. Dinakrisma, and R. M. S. Anggoro, "Tuberkulosis Sumsum Tulang pada Lupus Eritematosus Sistemik Berat: Sebuah Studi Kasus," J. Penyakit Dalam Indones., vol. 5, no. 2, p. 94, 2018, doi: 10.7454/jpdi.v5i2.180.

[3] A. Fatmawati, "Regulasi Diri Pada Penyakit Kronis - Systemic Lupus Erythematosus : Kajian Literatur," J. Keperawatan Indones., vol. 21, no. 1, pp. 43-50, 2018, doi: 10.7454/jki.v21i1.542.

[4] E. Hartati, "pengalaman klien systemic lupus erythematosus dalam melakukan yoga di kota semarang," J. Keperawatan Soedirman, vol. 7, no. 3, pp. 174-182, 2012.

[5] L. B. Rivai, P. Soewondo, and D. Irawati, "Pelayanan Penyakit Tidak Menular Terpadu ( PANDU ) sebagai Adaptasi World Health Organization ( WHO ) Package Essential of Noncommunicable Diseases Intervention ( PEN ) di Fasilitas Pelayanan Primer," Indon Med Assoc., vol. 65, no. 12, pp. 593-595, 2015.

[6] S. Gomathi and V. Narayani, "Monitoring of Lupus disease using Decision Tree Induction classification algorithm," ICACCS 2015 - Proc. 2nd Int. Conf. Adv. Comput. Commun. Syst., pp. 3-8, 2015, doi: 10.1109/ICACCS.2015.7324054.

[7] S. Waluyo, Penyakit-Penyakit Autoimun. 2014.

[8] S. Gomathi and V. Narayani, "Systemic Lupus Erythematosus manifestation using ID3 algorithm - A clinical analysis," 2014 Int. Conf. Data Min. Intell. Comput. ICDMIC 2014, 2014, doi: 10.1109/ICDMIC.2014.6954265.

[9] K. Paydar, S. R. Niakan Kalhori, M. Akbarian, and A. Sheikhtaheri, "A clinical decision support system for prediction of pregnancy outcome in pregnant women with systemic lupus erythematosus," Int. J. Med. Inform., vol. 97, pp. 239-246, 2017, doi: 10.1016/j.ijmedinf.2016.10.018.

[10] F. Ceccarelli et al., "Prediction of chronic damage in systemic lupus erythematosus by using machine-learning models," PLoS One, vol. 12, no. 3, pp. 1-13, 2017, doi: 10.1371/journal.pone.0174200.

[11] Rino, "Application of Neural Network Methods Based on Genetic Algorithm for Breast 
Cancer Prediction," Tech-E, vol. 1, no. 1, p. 37, 2017, doi: 10.31253/te.v1i1.19.

[12] E. Nurelasari, "Penerapan Metode Metode Neural Network Berbasis Algoritma Genetika Untuk Prediksi Penyakit Kanker Payudara," Speed - Sentra Penelit. Eng. dan Edukasi, vol. 10, no. 3, pp. 1-11, 2018.

[13] P. Arsi and O. Somantri, "Deteksi Dini Penyakit Diabetes Menggunakan Algoritma Neural Network Berbasiskan Algoritma Genetika," J. Inform. J. Pengemb. IT, vol. 3, no. 3, pp. 290-294, 2018, doi: 10.30591/jpit.v3i3.1008.

[14] D. Setiawan, R. N. Putri, and R. Suryanita, "Perbandingan Algoritma Genetika dan Backpropagation pada Aplikasi Prediksi Penyakit Autoimun," Khazanah Inform. J. Ilmu Komput. dan Inform., vol. 5, no. 1, pp. 21-27, 2019, doi: 10.23917/khif.v5i1.7173.

[15] D. Setiawan, R. N. Putri, and R. Suryanita, "implementasi algoritma genetika untuk prediksi penyakit autoimun," RABITJurnal Teknol. dan Sist. Inf. Univrab, vol. 4, no. 1, pp. 8-19, 2019.

[16] D. Jollyta, J. Johan, and A. Hajjah, "Genetic Algorithms to Optimizatize Lecturer Assessment's Criteria," IOP Conf. Ser. Earth Environ. Sci., vol. 97, no. 1, 2017, doi: 10.1088/1755-1315/97/1/012005.

\section{(i) (2)}

Digital Zone: Jurnal Teknologi Informasi dan Komunikasi is licensed under a_Creative Commons Attribution International (CC BY-SA 4.0) 